\title{
Penilaian Status Kesuburan dan Pengelolaan Tanah Sawah Tadah Hujan di Desa Umbu Pabal Selatan, Kecamatan Umbu Ratu Nggay Barat
}

\section{(Assessment of Fertility Status and Management of Rain-fed Rice Fields in Umbu Pabal Selatan Village, Umbu Ratu Nggay Barat District)}

\author{
Uska Peku Jawang \\ (Diterima Desember 2020/Disetujui Juli 2021)
}

\begin{abstract}
ABSTRAK
Sawah tadah hujan di Desa Umbu Pabal Selatan merupakan lahan pertanian yang setiap tahun selalu digarap untuk memenuhi kebutuhan pangan masyarakat desa. Kesuburan tanah menjadi informasi penting dalam mengelola sawah agar produksi padi meningkat. Penelitian ini bertujuan mengevaluasi status sifat tanah, kesuburan tanah, dan arah pengelolaan tanah sawah tadah hujan di desa tersebut. Metode yang digunakan adalah survei eksplorasi deskriptif dengan sampel tanah diambil secara sengaja. Hasil uji laboratorium menunjukkan bahwa pH tanah tergolong masam, $\mathrm{N}$-total termasuk sedang, P-tersedia rendah, K-tersedia sangat tinggi, kapasitas tukar kation tinggi, dan C-organik tinggi. Status kesuburan rendah (96,9 ha), sedang (194,6 ha), dan tinggi (160,3 ha). Arahan pengelolaan dalam meningkatkan kesuburan dan kekurangan unsur hara ialah dengan pemupukan dan penggenangan air.
\end{abstract}

Kata kunci: tanah sawah tadah hujan, kesuburan tanah, Desa Umbu Pabal Selatan

\section{ABSTRACT}

The rain-fed rice fields in Umbu Pabal Selatan Village are agricultural land that is always cultivated every year to meet the food needs of the villagers. Soil fertility is a piece of important information in managing rice fields to increase rice production. This study aims to evaluate the status of soil properties, soil fertility, and the direction of management of rain-sized rice fields in the village. The method used was descriptive exploration surveys with soil samples taken deliberately. Laboratory test results showed that soil $\mathrm{pH}$ is classified as acidic, $\mathrm{N}$-total is medium, $\mathrm{P}$ available is low, $\mathrm{K}$-available is very high, cation exchange capacity is high, and C-organic is high. Fertility status is low (96.9 ha), moderate (194.6 ha), and high (160.3 ha). Management direction in improving fertility and nutrient deficiency is by fertilizing and water-logging.

Keywords: rain-fed rice field, soil fertility, South Umbu Pabal Village

\section{PENDAHULUAN}

Minimnya informasi sifat atau ciri lahan menjadi salah satu kendala dalam usaha produksi tanaman yang mengakibatkan hasil produksi tidak maksimal. Dalam pengelolaan tanah sawah perlu diperhatikan ciri tanah sebagai media penyedia kebutuhan tanaman yang akan dibudidayakan, khususnya kebutuhan nutrisi tanaman. Pemenuhan kebutuhan nutrisi tanpa mengetahui status unsur hara dalam tanah akan menimbulkan defisiensi dan toksisitas unsur hara, memengaruhi degradasi tanah, dan mengakibatkan ketergantungan akan bahan organik atau hara tertentu serta menjadi keracunan bagi tanaman. Nuryani et al. (2019) penambahan unsur hara melalui pemupukan secara tepat sesuai kebutuhan hara tanah dan tanaman, karena berlebihan akan mengakibatkan penurunan kualitas tanah dan menyebabkan keracunan bagi tanaman. Lie et al. (2013)

Program Studi Agroteknologi Universitas Kristen Wira Wacana Sumba, JI. R. Suprapto No. 35, Waingapu, Prailiu, Sumba Timur 87116

Penulis Korespondensi: uska@unkriswina.ac.id mengemukakan bahwa usaha pertanian bergantung pada kesuburan tanah; tanah dengan hara rendah akan mengakibatkan input tinggi dan biaya mahal. Jadi, informasi mengenai kualitas dan kesuburan tanah sangat penting dalam usaha produksi tanaman.

Pemenuhan kebutuhan pokok, masyarakat Desa Umbu Pabal Selatan memanfaatkan lahan yang tersedia untuk budi daya tanaman padi, baik pada lahan sawah tadah hujan, dan lahan kering atau kebun. Lahan yang sering digarap yaitu lahan sawah sedangkan kebun sering dimanfaatkan untuk budi daya tanaman padi gogo dan palawija seperti jagung, ubi kayu, ubi jalar, ganyong, dan tanaman perkebunan maupun hortikultura. Alasannya, produktivitas padi sawah lebih tinggi bila dibandingkan dengan produktivitas padi gogo atau padi ladang. Menurut Irawan (2015), masalah usaha padi gogo lebih kompleks daripada usaha padi sawah terutama karena kesuburan tanah dan ketersediaan air tanah terbatas.

Sawah tadah hujan masih dikelola berdasarkan tradisi atau budaya, baik dari proses pengolahan sawah, pembibitan, dan perawatan tanaman. Masalah pada saat perawatan ialah kebutuhan nutrisi dan penanganan organisme pengganggu tanaman (OPT), 
yang dinilai berdasarkan gejala fisis yang teramati secara visual oleh tanaman. Sistem penanganan dengan pupuk kimia dan pestisida kimia mengakibatkan kualitas tanah yang semula subur dapat menjadi kurang subur. Terdapat beberapa faktor penyebabnya seperti pola tanam yang salah, penggunaan pupuk kimia dan pestisida kimia berlebihan, erosi, penggunaan lahan terus-menerus, yang mengakibatkan ketersediaan unsur hara atau kesuburan tanah akan terganggu. Puja et al. (2013) mengemukakan bahwa tindakan pengelolaan tanah seperti pemupukan terus-menerus tanpa informasi status kesuburan tanah mengakibatkan peningkatan unsur hara, $\mathrm{N}, \mathrm{P}, \mathrm{K}$ tinggi sehingga menimbulkan ketidakseimbangan hara dalam tanah dan kebutuhan tanaman sehingga produktivitas lahan akan menurun.

Kesuburan tanah menjadi tolok ukur dalam keberhasilan usaha budi daya tanaman, sebab status kesuburan tanah dapat menentukan produktivitas lahan budi daya. Menurut Pinatih (2015), kesuburan tanah menentukan jumlah unsur hara yang tersedia dan seimbang guna menjamin pertumbuhan dan perkembangan tanaman yang optimum. Kualitas setiap lahan berbeda-beda. Tanah sawah tadah hujan (non-irigasi) memiliki status ketersediaan unsur hara rendah bila dibandingkan dengan sawah irigasi, disebabkan minimnya ketersediaan air, dan masih bergantung pada curah hujan. Unsur hara pada tanah sawah tadah hujan tidak berimbang (Yartiwi et al. 2018).

Evaluasi kesuburan tanah merupakan tindakan untuk memilah-milah keharaan tanah dan pengelolaan tanah (Dikti 1991). Kualitas tanah sawah tadah hujan perlu dinilai untuk mengetahui status kesuburan tanah dan tindakan pengelolaan tanahnya. Hasil ini dapat menjadi informasi penting bagi petani wilayah Desa Umbu Pabal Selatan dalam pengembangan lahan sawah tadah hujan dengan meningkatkan produksi padi sawah pada setiap musimnya dan kualitas tanah terus terjaga. Penelitian ini bertujuan mengevaluasi ciri tanah dan status kesuburan tanah sawah tadah hujan serta tindakan pengelolaan yang akan diterapkan.

\section{METODE PENELITIAN}

Penelitian dilaksanakan di tiga lokasi sawah tadah hujan di Desa Umbu Pabal Selatan, Kecamatan Umbu Ratu Nggay Barat, Kabupaten Sumba Tengah yaitu Lairoba, Aukalebung, dan Marada Bakul. Sampel tanah dianalisis di Laboratorium Kimia Tanah Fakultas Pertanian Universitas Nusa Cendana. Pelaksanaan penelitian mulai bulan Februari 2019 sampai Juli 2019.

Metode penelitian yang digunakan adalah deskriptif eksploratif melalui survei. Sampel tanah sawah ditentukan secara sengaja (purposive sampling) di tiga lokasi tersebut berdasarkan luas lahan sawah dan jenis tanah, setiap lokasi dengan overlay peta dengan skala 1:50.000 (peta administrasi, peta penggunaan lahan, dan peta jenis tanah). Diperoleh 10 sampel berupa sampel komposit. Parameter uji laboratorium ialah $\mathrm{pH}$ tanah $\left(\mathrm{H}_{2} \mathrm{O}\right), \mathrm{N}$-total (Kjeldahl), P-tersedia (Olsen), Ktersedia $\left(\mathrm{NH}_{4} \mathrm{OAc} \mathrm{AAS}\right)$, kapasitas tukar kation (KTK) $\left(\mathrm{NH}_{4} \mathrm{Oac}\right)$, dan C-organik (pengabuan). Status kesuburan tanah dan ditentukan berdasarkan kriteria Pusat Penelitian Tanah Bogor (1995). Peta divisualkan dengan perangkat lunak pemetaan Arcview Ver 3.1 dan QGIS Ver. 2.8.8.

\section{HASIL DAN PEMBAHASAN}

\section{Ciri Tanah Sawah Tadah Hujan}

Topografi lahan sawah tadah hujan Desa Umbu Pabal Selatan adalah datar, terletak di dataran rendah dengan dikelilingi perbukitan yang mengakibatkan air hujan mengalir dari perbukitan menuju lahan sawah. Dengan demikian, sawah langsung tergenang oleh air hujan. Setiap lokasi memiliki ciri tanah yang berbeda, mengakibatkan hasil produksi padi sawah pun beragam. Jawang et al. (2017) menyimpulkan bahwa ciri tingkat kesuburan tanah di desa ini termasuk kategori rendah sampai sedang, dengan jenis inceptisol, mollisol, alfisol, dan entisol. Jenis tanah yang dominan ialah inceptisol dan mollisol. Terdapat tiga lokasi sawah tadah hujan di desa ini, yaitu Lairoba, Aukalebung, dan Marada Bakul.

Ciri tanah sawah untuk ketiga lokasi (Tabel 1) menunjukkan bahwa tanah di lokasi Lairoba memiliki $\mathrm{pH}$ masam, C-organik tinggi, nitrogen sedang, fosforus sedang, kalium sangat tinggi, dan KTK tinggi. Tanah Aukalebung berstatus $\mathrm{pH}$ tanah masam, C-organik tinggi, nitrogen sedang, fosforus rendah dan sedang, status kalium tinggi dan sangat tinggi, dan KTK tinggi. Di Marada Bakul, status pH tanah masam, C-organik rendah dan tinggi, status nitrogen rendah dan sedang, fosforus sangat rendah dan sedang, kalium sedang, tinggi, dan sangat tinggi, dan status KTK tinggi. Ketiga lokasi memiliki ciri yang berbeda; ciri tanah Lairoba dan Aukalebung hampir sama, tetapi status hara di Marada Bakul beragam. Perbedaan ciri tanah diindikasikan oleh jenis tanah, teknik pengelolaan lahan, ciri fisik dan biologi yang berbeda. Sakti et al. (2011) berpendapat bahwa perbedaan unsur hara setiap lokasi ditentukan oleh dua faktor, yaitu faktor bawaan seperti jenis tanah dan faktor dinamik antara lain pengolahan tanah, irigasi, pemupukan, dan pengembalian sisa pascapanen.

\section{Derajat Keasaman (pH)}

$\mathrm{pH}$ tanah dapat dijadikan sebagai acuan dalam menilai kualitas atau kesehatan tanah, dalam rangka pemenuhan kebutuhan media tumbuh tanaman. Lantoi et al. (2016) menyatakan bahwa reaksi tanah $(\mathrm{pH})$ bukan hanya menunjukkan keasaman atau kebasaan, tetapi dapat memperlihatkan sifat fisik, kimia, dan biologi tanah. Berdasarkan parameter $\mathrm{pH}$, nilai $\mathrm{pH}$ termasuk pada kategori tanah masam (Tabel 1). Ditinjau dari kesehatan tanah, tanah tersebut kurang sehat. Lantoi et al. (2016) menerangkan bahwa tanah 
Tabel 1 Tabel ciri tanah sawah tadah hujan Desa Umbu Pabal Selatan

\begin{tabular}{ccccccc}
\hline $\begin{array}{c}\text { Titik } \\
\text { sampel }\end{array}$ & $\mathrm{pH}$ & C-Organik (\%) & N-Total $(\%)$ & $\begin{array}{c}\text { P-Tersedia } \\
(\mathrm{ppm})\end{array}$ & $\begin{array}{c}\text { K-Tersedia } \\
(\mathrm{me} / 100 \mathrm{~g})\end{array}$ & $\mathrm{KTK}(\mathrm{me} / 100 \mathrm{~g})$ \\
\hline LB 1 & $5,06(\mathrm{M})$ & $3,57(\mathrm{~T})$ & $0,26(\mathrm{~S})$ & $16,33(\mathrm{R})$ & $1,09(\mathrm{ST})$ & $33,20(\mathrm{~T})$ \\
LB 2 & $4,98(\mathrm{M})$ & $4,83(\mathrm{~T})$ & $0,37(\mathrm{~S})$ & $23,89(\mathrm{R})$ & $1,50(\mathrm{ST})$ & $29,92(\mathrm{~T})$ \\
AB 1 & $5,45(\mathrm{M})$ & $4,23(\mathrm{~T})$ & $0,32(\mathrm{~S})$ & $20,44(\mathrm{R})$ & $1,31(\mathrm{ST})$ & $32,82(\mathrm{~T})$ \\
AB 2 & $4,78(\mathrm{M})$ & $4,20(\mathrm{~T})$ & $0,32(\mathrm{~S})$ & $20,05(\mathrm{R})$ & $1,29(\mathrm{ST})$ & $31,54(\mathrm{~T})$ \\
AB 3 & $4,82(\mathrm{M})$ & $3,17(\mathrm{~T})$ & $0,23(\mathrm{~S})$ & $13,97(\mathrm{R})$ & $0,96(\mathrm{~T})$ & $33,59(\mathrm{~T})$ \\
AB 4 & $4,91(\mathrm{M})$ & $4,18(\mathrm{~T})$ & $0,32(\mathrm{~S})$ & $19,86(\mathrm{R})$ & $1,28(\mathrm{ST})$ & $31,44(\mathrm{~T})$ \\
MB 1 & $5,19(\mathrm{M})$ & $1,57(\mathrm{R})$ & $0,10(\mathrm{R})$ & $4,80(\mathrm{SR})$ & $0,46(\mathrm{~S})$ & $33,88(\mathrm{~T})$ \\
MB 2 & 5,23 (M) & $1,82(\mathrm{R})$ & $0,12(\mathrm{R})$ & $6,33(\mathrm{SR})$ & $0,55(\mathrm{~T})$ & $39,21(\mathrm{~T})$ \\
MB 3 & $5,38(\mathrm{M})$ & $4,07(\mathrm{~T})$ & $0,31(\mathrm{~S})$ & $19,67(\mathrm{R})$ & $1,27(\mathrm{ST})$ & $34,16(\mathrm{~T})$ \\
MB 4 & 5,09 (M) & $1,40(\mathrm{R})$ & $0,09(\mathrm{SR})$ & $3,90(\mathrm{SR})$ & $0,42(\mathrm{~S})$ & $36,67(\mathrm{~T})$ \\
\hline
\end{tabular}

Sumber: Pusat Penelitian Tanah, 1995.

Keterangan: $\mathrm{M}=$ Masam, $\mathrm{SR}=$ Sangat rendah, $\mathrm{R}=$ Rendah, $\mathrm{S}=$ Sedang, $\mathrm{T}=$ Tinggi, $\mathrm{ST}$ = Sangat tinggi .

dengan nilai $\mathrm{pH} 4,5-6,5$ merupakan tanah dengan tingkat kesehatan kurang sehat.

Arahan peningkatan $\mathrm{pH}$ ialah dengan menambahkan bahan organik melalui pemupukan. Menurut Ch'Ng et al. (2014), tambahan bahan organik dapat meningkatkan $\mathrm{pH}$ tanah dan pada saat yang sama dapat mengurangi Al-dd dan Fe-dd yang mengikat unsur hara yang diserap tanaman. Olafisoye et al. (2016) menambahkan bahwa bahan organik merupakan donor elektron yang dapat menyumbang reaksi reduksi logam-logam pada $\mathrm{pH}$ tanah yang rendah.

\section{C-Organik}

C-organik merupakan salah satu unsur utama penyusun bahan organik dalam tanah, berupa sisasisa tanaman dan tumbuhan serta hewan dari berbagai tingkat dekomposisi. C-organik berperan menyediakan media tumbuh yang baik yang dibutuhkan tanaman. Corganik dapat menentukan ciri fisik, kimia, dan biologi tanah. Berdasarkan Tabel 1, nilai persentase Corganik tanah sawah tadah hujan di Desa Umbu Pabal Selatan adalah 1,40-4,83; jika dikategorikan berdasarkan Pusat Penelitian Tanah (1995) berada dalam status rendah dan tinggi. Pada kedua lokasi, yaitu Lairoba dan Aukalebung, kandungan C-organik termasuk tinggi, sedangkan kategori pada Marada Bakul adalah rendah.

Perbedaan status organik yang tersedia dalam tanah dapat disebab oleh beberapa faktor seperti jenis tanah dan ciri fisik tanah (tekstur, permeabilitas, aerasi, dan porositas tanah). Darmawijaya (1990) menjelaskan bahwa ciri fisik tanah dapat memengaruhi ciri kimia dan biologi dalam tanah. Salah satu faktor lain yang mungkin adalah kebiasaan beberapa petani setempat ialah membakar jerami dan sisa-sisa limbah panen; akibatnya, tidak terjadi proses dekomposisi sehingga kandungan C-organiknya rendah.

Kandungan C-organik tanah sawah tadah hujan Desa Umbu Pabal Selatan sangat tinggi. Keadaan ini mungkin dipengaruhi oleh pengolahan sawah pada saat musim hujan dan kebiasaan petani membiarkan residu tanaman padi dan gulma pada lahan sawah. Pinatih et al. (2015) mengemukakan bahwa pemanfaatan jerami sebagai bahan organik akan meningkatkan kesuburan tanah dan unsur hara makro maupun mikro yang diperlukan oleh tanaman. Ginting et al. (2013) menambahkan bahwa sumber bahan organik yang tinggi berasal dari tanaman yang melakukan proses fotosintesis. Bagian tanaman yang menjadi sumber organik adalah daun, rerumputan, gulma, dan sisa limbah pascapanen seperti jerami padi.

\section{N-Total}

Nitrogen merupakan unsur hara yang sangat dibutuhkan tanaman dalam jumlah banyak. Bentuk $\mathrm{N}$ yang diserap oleh tanaman adalah amonium $\left(\mathrm{NH}_{4}{ }^{+}\right)$ dan nitrat $\left(\mathrm{NH}_{3}{ }^{+}\right)$sehingga nilai $\mathrm{N}$-total tanah menentukan jumlah yang tersedia bagi tanaman, sebab senyawa nitrogen tersebut mudah larut dan hilang ke atmosfer pada saat irigasi. Nitrogen tersedia dalam bentuk $\mathrm{N}$ organik yang dapat larut dan tersedia. Menurut Wild (1981) nitrogen yang tidak terjerap oleh koloid tanah sehingga tersedia bagi tanaman, cepat hilang, dan terlarut dalam air. Berdasarkan Tabel 1, status harkat $\mathrm{N}$-total sawah tadah hujan di Desa Umbu Pabal Selatan sangat rendah, rendah, dan sedang, dengan nilai $\mathrm{N} 0,09-0,37$. Untuk lokasi Lairoba dan Aukalebung, status nitrogen sedang, sedangkan untuk lokasi Marada Bakul beragam, yaitu sangat rendah, rendah, dan sedang.

Terdapat beberapa faktor yang mengakibatkan ketersediaan $\mathrm{N}$ dalam tanah terbatas, antara lain (1) sifat nitrogen yang sangat mudah bergerak, (2) pencucian hara $\mathrm{N}$ oleh air hujan, (3) terangkut saat panen, (4) terikat oleh mineral tanah, dan (5) dimanfaatkan oleh organisme (Ginting et al. 2013). Menurut Sakti et al. (2011), ciri fisik tanah dapat memengaruhi ketersediaan $\mathrm{N}$ dalam tanah. Bila diperhatikan bahwa ketersediaan $\mathrm{N}$ dalam tanah berbanding lurus dengan ketersediaan bahan organik dalam tanah. Faktor lainnya adalah ketersediaan air yang terbatas yang mengakibatkan proses dekomposisi oleh mikroorganisme dalam tanah tidak berjalan, sehingga $\mathrm{N}$-total tanah pun terbatas.

\section{P-Tersedia}

P-tersedia adalah unsur $P$ tanah yang dapat terlarut dalam air dan asam sitrat, dengan $P$ yang terlarut 
dalam air merupakan unsur $\mathrm{P}$ yang dapat diserap oleh tanaman. Fosforus anorganik berupa senyawa kompleks Al-P, Fe-P, dan Ca-P, bersifat alkali, tidak terlarut, sehingga tidak tersedia untuk tanaman. Menurut Damanik et al. (2010), bentuk fosfat anorganik terikat dengan unsur logam. Umaternate et al. (2014) mengatakan bahwa unsur $\mathrm{P}$ yang dapat diserap oleh tanaman ialah dalam bentuk $\mathrm{H}_{2} \mathrm{PO}^{4-}, \mathrm{HPO}_{4}{ }^{2-}$, dan $\mathrm{PO}_{4}{ }^{3-}$ dalam larutan tanah. Berdasarkan Tabel 1, kandungan $\mathrm{P}$ dalam tanah sawah tadah hujan Desa Umbu Pabal Selatan adalah 3,90-23,89 ppm; termasuk dalam kategori sangat rendah dan rendah. Pada lokasi Lairoba dan Aukalebung, status $\mathrm{P}$ adalah rendah, sedangkan pada lokasi Marada Bakul statusnya beragam, yaitu sangat rendah dan rendah. Dengan status $\mathrm{P}$ tersebut, maka diperlukan tambahan melalui pemupukan. Salah satu faktor rendahnya kandungan $\mathrm{P}$ ialah rendahnya kandungan organik pada lokasi tersebut. Dikti (1991) menjelaskan bahwa kecenderungan rendahnya fosforus dalam tanah dipengaruhi oleh bahan organik, ketersediaan air, dan mineral-mineral yang terdapat dalam tanah.

Faktor yang memengaruhi ketersediaan $\mathrm{P}$ dalam tanah yaitu (1) C-organik, (2) pH tanah, (3) kandungan $\mathrm{Fe}, \mathrm{Al}$, dan Ca, dan (4) ciri fisik tanah. Sakti et al. (2011) berpendapat bahwa perbedaan ketersediaan $P$ dalam tanah dipengaruhi oleh ordo tanah, misalkan pada ordo inceptisol, kandungan $\mathrm{P}$ tergolong rendah karena kandungan mineral kaokolinik. Goswani (1986) mengungkapkan bahwa dalam sawah tadah hujan sering terjadi fiksasi P dengan Al dan Fe dalam bentuk Al-P dan Fe-P, akibat pergantian kondisi kering dan basah yang berkepanjangan. Rendahnya unsur $\mathrm{P}$ dan meningkatnya kandungan $\mathrm{Al}$ kondisi tanah kering, dan tinggi kandungan $\mathrm{Fe}$ pada kondisi tanah tergenang air. Faktor yang berkorelasi positif dengan kandungan $\mathrm{P}$ tersedia dalam tanah adalah $\mathrm{pH}$, sebab P-tersedia dan dapat diserap oleh tanaman pada rentang $\mathrm{pH} 6,0-7,0$.

\section{K-Tersedia}

Kalium tersedia adalah bentuk $\mathrm{K}$ yang dapat diserap oleh tanaman, dengan kalium tanah berada pada keseimbangan bentuk, yaitu mineral, terfiksasi, dapat-dipertukarkan, dan terlarut dalam air. Menurut Rahma et al. (2014), bahwa unsur K yang diserap oleh tanaman dalam bentuk ion $\mathrm{K}+$ Muatan positif akan membantu menetralkan muatan listrik yang dibentuk oleh nitrat, fosfat, $\mathrm{Ca}, \mathrm{Mg}$, dan unsur lainnya.

Hasil analisis (Tabel 1) menggambarkan kandungan $\mathrm{K}$ dari 0,42 sampai $1,50 \mathrm{me} / 100 \mathrm{~g}$; termasuk kategori sedang, tinggi, dan sangat tinggi. Bila dikelompokkan ke dalam status kesuburan, Ktersedia termasuk sangat tinggi. Keadaan ini dapat dipengaruhi oleh sisa-sisa hasil panen yang tertinggal, jerami padi tersebar, sisa penggunaan pupuk, dan tergenang air irigasi dalam waktu yang cukup lama, mengakibatkan terendapnya kalium. Tingginya harkat $\mathrm{K}$ disebabkan oleh nilai KTK yang tinggi. Menurut Suseno et al. (2018), meningkatnya K-tersedia ialah karena kemampuan tanah dalam menahan $\mathrm{K}$ dan menurunkan sifat pencucian kalium. Pinatih et al. (2015) menjelaskan bahwa topografi datar dapat menyebabkan kandungan $\mathrm{K}$ sangat tinggi, disebabkan oleh pengendapan kalium dalam tanah. Lokasi sawah tadah hujan dalam studi ini terletak pada daerah terendah dan dikelilingi perbukitan. Dari ketiga lokasi, Lairoba dan Aukalebung memiliki kandungan $\mathrm{K}$ tinggi dan sangat tinggi, sedangkan Marada Bakul beragam, yaitu sedang, tinggi, dan sangat tinggi. Rahma et al. (2014) berargumen bahwa status $\mathrm{K}$ sangat tinggi adalah karena kalium terletak pada permukaan tanah; bila semakin dalam statusnya semakin rendah.

Kandungan $\mathrm{K}$ beragam di Marada Bakul, kemungkinan karena ciri fisik tanah, kimia tanah, curah hujan yang tinggi, dan teknik pengelolaan. Ketersediaan $\mathrm{K}$ tanah sedang, diindikasikan oleh miskin kandungan kation-kation basa, yang dipengaruhi oleh pencucian $\mathrm{K}$ oleh air dan terserap oleh tanaman (terangkut) tanpa pengembalian dengan metode pemupukan ataupun pengapuran.

\section{Kapasitas Tukar Kation}

KTK merupakan salah satu indikator dalam menentukan status kesuburan tanah, sebab terdapat koloid tanah yang dapat menentukan jumlah kation yang dapat diserap dan dipertukarkan dengan jumlah yang tersedia untuk tanaman. Kation basa (Ca, Mg, K, dan $\mathrm{Na}$ ) memiliki kejenuhan yang tinggi dan terlarut dalam air sehingga tersedia nutrisi bagi tanaman. Sudaryono (2009) mengatakan bahwa nilai KTK dapat menentukan kemudahan unsur hara yang dapat diserap oleh tanaman. Kation-kation yang dijerap oleh koloid tanah dapat diganti dengan unsur kation lainnya, kation yang dapat dipertukarkan, tidak mudah hilang dan tercuci oleh air, sehingga dapat tersedia untuk tanaman.

Hasil pengujian tanah sawah (Tabel 1) menggambarkan nilai KTK kategori tinggi, yakni 29,92-39,21 me/100g. Dengan status KTK tinggi, ada kemungkinan bahwa pengolahan lahan yang hanya dilakukan pada saat musim hujan, sehingga pemanfaatan unsur kation dalam tanah rendah dan pengaruh sisa pascapanen tanaman padi dan pencucian unsur kation juga sangat kecil. Pinatih et al. (2015) mengatakan bahwa jenis tanah yang tergolong pada kategori muda dan berkembang mempunyai nilai KTK tinggi sebab belum banyak terjadi pencucian unsur-unsur kation basa dalam tanah.

Tingginya nilai KTK disebabkan oleh kandungan Corganik yang tinggi. Rahma et al. (2014) menjelaskan bahwa KTK berkorelasi positif dengan ketersediaan bahan organik dalam tanah. Meningkatnya humus karena jumlah bahan organik yang tinggi mengakibatkan jumlah koloid tanah meningkat sehingga KTK dalam tanah status haranya akan tinggi. Hubungan C-organik dan KTK di Lairoba dan Aukalebung linear, yaitu C-organik tinggi dan KTK tinggi. Namun, tidak demikian di Marada Bakul, Corganik rendah tetapi status KTK tinggi. Terdapat beberapa faktor, yaitu sifat koloid tanah dan 
terbatasnya ketersediaan air yang mengakibatkan unsur kation berikatan dengan senyawa anorganik seperti Al. Sufardi et al. (2017) daerah dengan iklim kering memiliki KTK rendah disebabkan sistem muatan variabel dan memiliki aktivitas liat yang rendah, liat aktivitas rendah karena komposisi tanah tersusun fraksi-fraksi oksida dan hidroksida $\mathrm{Fe}$ dan $\mathrm{Al}$ yang mengandung muatan negatif. Hubungan KTK dan bahan organik tidak positif, sebab pada lahan kering bahan organik cepat menurun berkisar 30-60\% dengan kurun waktu 10 tahun.

\section{Penilaian Status Kesuburan Tanah}

Berdasarkan hasil penilaian hasil kombinasi indikator ciri tanah pada ketiga lokasi sawah tadah hujan di Desa Umbu Pabal Selatan, didasarkan pada ciri tanah (Pusat Penelitian Tanah 1995), dilanjutkan dengan analisis spasial, maka status kesuburan tanah sawah tadah hujan ialah rendah, sedang, dan tinggi dapat terlihat pada peta kesuburan. Kelas kesuburan tanah sawah untuk setiap lokasi adalah sebagai berikut: Lairoba dengan status tinggi, Aukalebung dengan status sedang dan tinggi, sedangkan Marada Bakul dengan status rendah, sedang, dan tinggi. Luas setiap kategori ialah rendah (96,9 ha), sedang $(194,6$ ha), dan tinggi (160,3 ha) (Gambar 1).

\section{Arahan Pengelolaan Kesuburan Tanah Sawah}

Berdasarkan hasil penilaian status hara tanah sawah di Desa Umbu Pabal Selatan, yang menjadi faktor pembatas kesuburan tanah ialah $\mathrm{pH}$ yang masam, nilai nitrogen rendah, dan fosforus sedang. Tiga rekomendasi untuk memperbaiki faktor pembatas ini, yakni pemupukan, pengolahan tanah, dan konservasi air.

Pupuk diaplikan dengan cara menambahkan bahan organik ke dalam tanah. Pinatih et al. (2015) mengatakan bahwa pemberian bahan organik akan meningkatkan nilai $\mathrm{P}$, sebab bahan organik dapat berperan dalam (1) membentuk organofosfat kompleks yang mudah diserap oleh tanaman, (2) pergantian $\mathrm{H}_{2} \mathrm{PO}_{4}{ }^{-}$terhadap jerapan tanah, (3) menyelimuti unsur oksida Fe dan Al oleh humus agar tidak terjadi jerapan berlebihan terhadap $\mathrm{P}$, dan (4) meningkatkan jumlah $\mathrm{P}$ organik yang diikat oleh $\mathrm{P}$ anorganik. Rekomendasi pemupukan berbasis pemetaan (Gambar 1, skala 1:50.000), berdasarkan spesifik lokasi dengan budi daya tanaman padi (Permentan 2007; Mario et al. 2008) ialah dengan pupuk urea $200 \mathrm{~kg} / \mathrm{ha}$, NPK 150 kg/ha, SP-36 100 kg/ha, KCl 50 kg/ha, dan Phonska $200 \mathrm{~kg} / \mathrm{ha}$.

Kandungan unsur hara $\mathrm{N}$ dan $\mathrm{P}$ pada sawah tadah hujan yang terbatas dikelola dengan penggenangan. Sakti et al. (2011) menyarankan bahwa penggenangan akan meningkatkan kandungan $\mathrm{N}$-total tanah sebab air tanah sawah tadah hujan dapat memberi masukan 1$2 \mathrm{~kg} / \mathrm{ha} / \mathrm{musim}$. Bila tersedia, Iahan sawah dapat di irigasi guna meningkatkan kandungan $\mathrm{N}$-total 8,51$10,17 \mathrm{~kg} / \mathrm{ha} / \mathrm{musim}$. Penggenangan 10 hari dapat meningkatkan amonium sekitar 300 ppm dan penggenangan 30 hari meningkatkan 335 ppm. Kandungan $\mathrm{P}$ ditingkatkan dengan teknik irigasi; sumbangan hara $P$ berkisar dari 0 sampai 3 $\mathrm{kg} / \mathrm{ha} /$ musim. Tersedianya unsur $P$ pada air irigasi disebabkan oleh hasil pelarutan mineral, erosi, pemupukan, dan kegiatan biologi air.

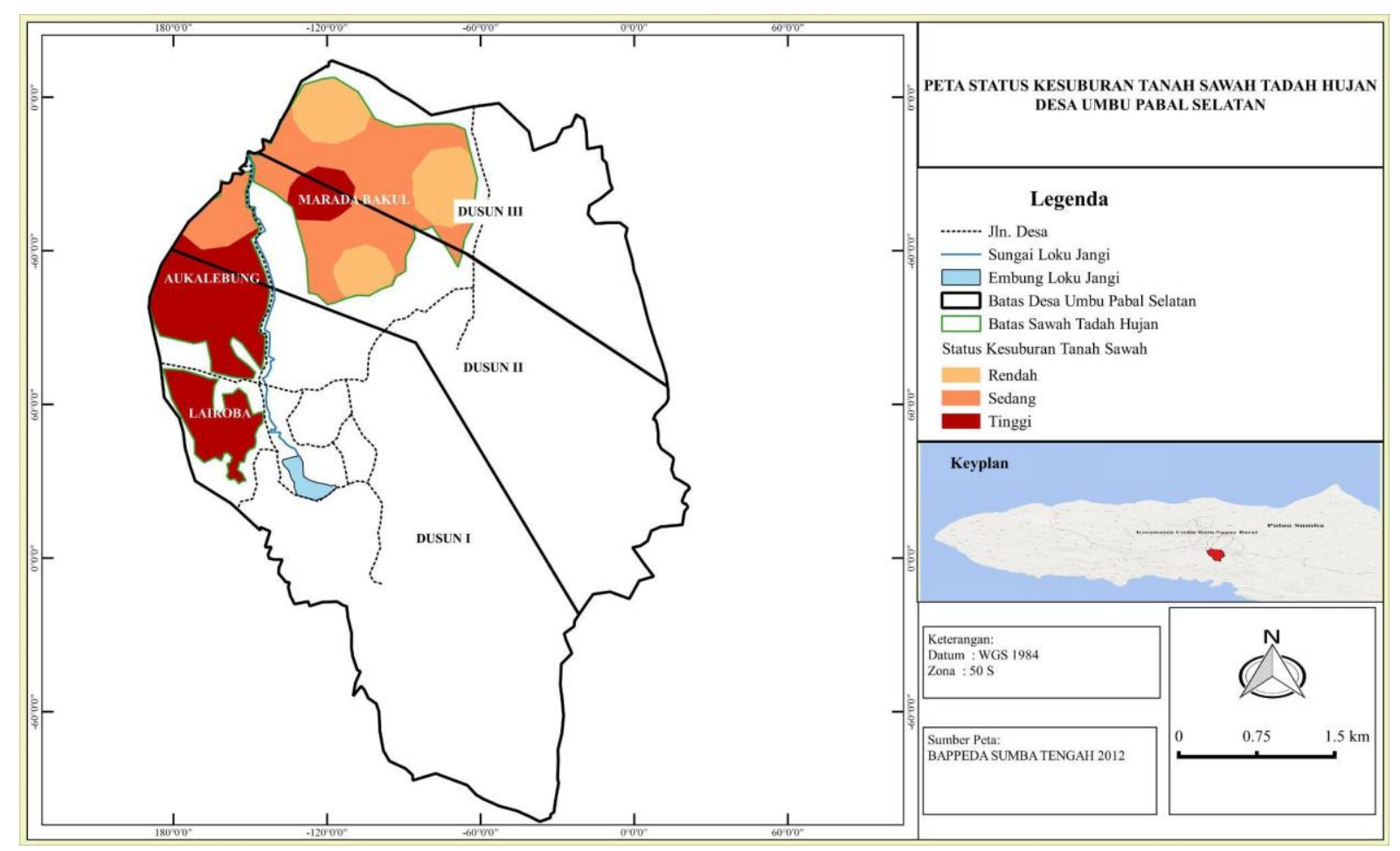

Gambar 1 Peta status kesuburan tanah sawah tadah hujan Desa Umbu Pabal Selatan. 


\section{KESIMPULAN}

Berdasarkan kajian sifat tanah sawah tadah hujan di Desa Umbu Pabal Selatan, pH tergolong masam, Corganik tinggi, nitrogen sedang, fosforus rendah, kalium sangat tinggi, dan KTK tergolong tinggi. Dari hasil kombinasi sifat tanah, status kesuburan tanah termasuk rendah, sedang, dan tinggi. Luas setiap kategori status kesuburan tanah ialah rendah (seluas 96,9 ha), sedang (seluas 194,6 ha), dan tinggi (seluas 160,3 ha). Status kesuburan tanah setiap lokasi ialah tinggi untuk Lairoba, status sedang dan tinggi untuk Aukalebung, dan status rendah, sedang, dan tinggi untuk Marada Bakul. tinggi. Faktor pembatas kesuburan tanah ialah $\mathrm{pH}$ yang masam, fosforus rendah, dan nitrogen sedang.

Berdasarkan status kesuburan tanah dan faktor pembatasnya, direkomendasikan untuk mengelola tanah sawah tadah hujan di Desa Umbu Pabal Selatan dengan pemupukan dan konservasi air. Jenis dan jumlah pemupukan berupa pupuk urea $200 \mathrm{~kg} / \mathrm{ha}$, NPK $150 \mathrm{~kg} / \mathrm{ha}, \mathrm{SP}-36100 \mathrm{~kg} / \mathrm{ha}, \mathrm{KCl} 50 \mathrm{~kg} / \mathrm{ha}$, dan Phonska 200 kg/ha.

\section{DAFTAR PUSTAKA}

Al-Jabri M. 2008. Kajian Metode Penetapan Kapasitas Tukar Kation Zeolit Sebagai Pembenah Tanah Untuk Lahan Pertanian Terdegradasi. Jurnal Standardisasi 10(2): 56-59.

Ch'Ng, HY, OH Ahmed, NMA Majid. 2014. Improving Phosphorus Availability In An Acid Soil Using Organic Amendments Produced From Agroindustrial Wastes. The Scientific World Journal. https://doi.org/10.1155/2014/506356

Damanik MMB, Bachtiar EH, Fauzi, Sariffudin, Hanum H. 2010. Kesuburan Tanah dan Pemupukan. Medan (ID): USU Press

Darmawijaya I. 1990. Klasifikasi Tanah: Dasar Teori bagi Peneliti Tanah dan Pelaksana Pertanian di Indonesia. Yogyakarta (ID). Gadjah Mada University Press.

[Dikti] Direktorat Jenderal Pendidikan Tinggi. 1991. Kesuburan Tanah. Jakarta (ID): Departemen Pendidikan dan Kebudayaan.

Ginting, Rosmenda, Sulkifli N. 2013. Pemetaan Status Unsur Hara C-Organik Dan Nitrogen Di Perkebun Nanas (Ananas comosus L. Merr) Rakyat Desa Panribuan Kecamatan Dolok Silau Kabupaten. Jurnal Online Agroekoteknologi 1(4): 1308-1318
Goswani NN. 1986. Soil Tests as A Guide to Fertilizer Needs of Irrigated Rice. Fertilizer News 31(9): 26-33

Irawan, Bambang. 2015. Dinamika Produksi Padi Sawah dan Padi Gogo: Implikasinya Terhadap Kebijakan Peningkatan Produksi Padi. Badan Litbang Pertanian http://www.litbang.pertanian. go.id/buku/swasembada/

Jawang UP, Bistok HS, Tinjung MP. 2017. Evaluasi Zona Agroekologi Kabupaten Sumba Tengah Berbasis Sistem Informasi Geografis. Konser Karya Ilmiah Nasional 2017 - Menghadapi Tantangan dan Meraih Kemandirian Pertanian Indonesia $5 \mathrm{Mei}$ 2017. Salatiga (ID).

Lantoi RR, Saiful D, Yosep P, Patadungan. 2016. Identifikasi Kualitas Tanah Sawah Pada Beberapa Lokasi di Lembah Palu Dengan Metode Skoring Lowery. Agroland. 23(3): 243-250.

Lie W, Zhang Y, Wang C, Mao W, Hang T, Chen M, Zhang B. 2013. How to Evaluate the Rice Cultivation Suitability. Asian Agricultural Research. 5(12): 59-64.

Mario, Muljady D, Annas Z, Aisyah A, Fatmah S, Rony P, Tina F. 2008. Petunjuk Teknik Rekomendasi Pemupukan Padi Sawah Spesifik Lokasi. Balai Pengkajian Teknologi Pertanian Gorontalo. Gorontalo (ID).

Nuryani E, Gembong H, Historiawati. 2019. Pengaruh Dosis Dan Saat Pemberian Pupuk P Terhadap Hasil Tanaman Buncis (Phaseolus vulgaris, L.) Tipe Tegak. VIGOR: Jurnal IImu Pertanian Tropika dan Subtropika. 4(1): 14-17.

Olafisoye BO, Oguntibeju OO, Osibote OA. 2016. An assessment of the bioavailability of metals in soils on oil palm plantations in Nigeria. Polish Journal of Environmental Studies. 25(3): 1125-1140. https://doi.org/10.15244/pjoes/60858

Permentan, 2007. Peraturan Kementrian Pertanian No. 40/Permentan/OT.140/2007 tentang Rekomendasi Pemupukan N, P dan K Pada Padi Sawah Spesifik Lokasi.

Puja IN, Supadma AAN, Mega IM. 2013. Kajian Unsur Hara Tanah Sawah Untuk Menentukan Tingkat Kesuburan. Journal on Agriculture Science 3(2): 51-56. 
Pusat Penelitian Tanah Bogor .1995. Kombinasi Beberapa Sifat Kimia Tanah dan Status Kesuburanya. Bogor (ID).

Rahma, Siti, Yusran, Husain U. 2014. Sifat Kimia Tanah Pada Berbagai Tipe Penggunaan Lahan Di Desa Bobo Kecamatan Palolo Kabupaten Sigi. Warta Rimba. 2(1): 88-95

Pinatih, Dewa KASR, Tati BK, Ketut DS. 2015. Evaluasi Status Kesuburan Tanah Pada Lahan Pertanian Di Kecamatan Denpasar Selatan. EJurnal Agroekoteknologi Tropika. 4(4): 282-292.

Sakti, Pramuda, Purwanto, Slamet M, Sutopo. 2011. Status Ketersediaan Makronutrisi (N, P, dan K) tanah sawah dengan Teknik dan Irigasi Tadah Hujan di Kawasan Industri Karanganyar,Jawa Tengah. Bonorowo Wetlands. 1(1): 8-19.

Sudaryono. 2009. Tingkat Kesuburan tanah Ultisol pada Lahan Pertambangan Batu Bara Sangatta Kaltim. Jurnal Teknologi Lingkungan. 10(3): 337-346. https://doi.org/10.29122/jtl.v10i3.1480

Sufardi, Lukman M, Muyassir. 2017. Pertukaran Kation pada Beberapa Jenis Tanah di Lahan Kering Kabupaten Aceh Besar Provinsi Aceh (Indonesia).
Prosiding Seminar Nasional Pascasarjana (SNP) Unsyiah: Banda Aceh (ID).

Suseno, Andi, Dyah A, Santoso AZPB. 2018. Evaluasi Status Kesuburan Tanah di Desa Nglegi, Kecamatan Patuk, Kabupaten Gunungkidul, Daerah Istimewa Yogyakarta. Jurnal Tanah dan Air 15(1): 47-54.

Umaternate GS, Jemmy A, Audi DW. 2014. Uji Metode Olsen dan Bray dalam Menganalisis Kandungan Fosfat Tersedia pada Tanah Sawah di Desa Konarom Barat Kecamatan Dumogo Utara. MIPA Unstrat Online 3(1): 6-10. https://doi.org/ 10.35799/jm.3.1.2014.3898

Wild A. 1981. Mass Flow and Diffusion in D.J. Grreenland and M.H.B. Hayes (eds). The Chemistry of Soil Processes. John Wiley \& Sons. New York (US).

Yartiwi, Atra R, Satria P. Utama. 2018. Uji Adaptasi Varietas Unggul Baru Padi Sawah Untuk Optimasi Lahan Tadah Hujan Berwawasan Lingkungan di Kabupaten Seluma Provinsi Bengkulu. Penelitian Pengelolaan Sumberdaya Alam Dan Lingkungan. 7(2): 91-97. https://doi.org/10.31186/naturalis. 7.2.6027 